doi: $10.15503 /$ jecs20182.38.51

\title{
“GOD'S NOT DEAD 2" DILEMMA: SELECTED RELIGIOUS LIBERTY ISSUES OF K-12 SCHOOL TEACHERS
}

\author{
IWONA ZAMKOWSKA \\ Faculty of Philology and Pedagogy \\ Kazimierz Pulaski University of Technology and Humanities in Radom, \\ ul. Chrobrego 31, 26-600 Radom \\ Email address: i.zamkowska@uthrad.pl
}

\begin{abstract}
Aim. The aim of the research is to confirm whether God's Not Dead 2 production is an adequate portrayal of religious liberty of school officials in K-12 schools in the USA. The author limited the discussion to the essential problem questions inspired by the production, such as teachers' right to express their religious views both in a class discussion, and out-of-class informal exchange with students and fellow faculty members.

Methods. The problem was discussed against the backdrop of selected legal and legislative acts that determine the scope of teachers' religious expression, such as selected courts' decisions, official federal guidelines issued by the Department of Education as well as the guides published by non-government organizations. The results of the Bible Literacy Project as well as interviews with school officials were utilized to further verify the basic concepts of the research. The source texts were analysed using a close reading method.

Results. The study seems to prove that the movie script is symptomatic of real-life scenarios teachers face in American schools in terms of their legal liability; however, due to the complexity of the legal system as well as the discrepancy between the lines of decisions reached in lower courts, it is difficult to unambiguously assess the probability of the favorable outcome of the dispute.

Conclusions. The teacher-related tensions between church and state may negatively impact classroom atmosphere, create the risk of jeopardizing the education of the youth on the rights of citizens, and enhance the trend to resort to homeschooling for religious reasons.

Key words: religious liberty, K-12 schools, public employees' speech rights, religious expression
\end{abstract}

\section{INTRODUCTION}

It is a regular day in a high school in the United States. Ms. Wesley, a History teacher, discusses the origins of a nonviolent movement with her students. Her tone of voice and gesture enhance the significance of the lofty ideals of its founder, Mahatma Gandhi. Dozens of students follow closely, trying to 
comprehend every word of the lecture. Nothing seems to break the routine of the day until a hand goes up. "Isn't that sort of like what Jesus meant when he said that we should love our enemies?" a student's question breaks the silence. "Yes", replies the teacher, somewhat hesitantly, "The writer of the Gospel of Matthew records Jesus as saying, 'You have heard it said, 'love your neighbor and hate your enemy, 'but I tell you, love your enemies and pray for those who persecute you, that you will be children of your Father in heaven'". "Which indicates a commitment to nonviolence", the teacher immediately links the Scripture to the topic discussed. The exchange continues for a while culminating with the teacher's solemn statement: "But I, for one, am grateful for those that do, you know, those who stand up for what they believe" (Cronk, 2016). Little did she know how soon her own ability to stand up for her beliefs would be tested in the court of law.

Did the author of the script go too far staging a court trial of his protagonist as a consequence of her replying to a student's innocent question, or is it symptomatic of real-life scenarios religious teachers face in American schools? If so, how far does the scope of freedom of school officials extend and what determines what freedom they can enjoy in their interactions with students and fellow teachers? This paper will attempt to address these problem questions.

\section{THE SOURCES OF REGULATIONS DETERMINING THE SCOPE OF TEACHERS' RELIGIOUS EXPRESSION}

The film jury acquits Ms. Wesley of all the charges, yet in real life, scenarios are often much more complex and diverse. One of the reasons is the nature of the legal system public school teachers are subjected to as they work in their capacity as state officials. When the main protagonist, Ms. Wesley, is summoned for questioning by the school board, the principal resolves to refer the case to "the court of competent jurisdiction", and the charges brought against the teacher are to be verified on the basis of her compliance with district policy, as well as local, state, and federal guidelines (Cronk, 2016). In school reality, as stated in Teachers and Religion in Public Schools, the law indeed consists of multiple levels starting with contractual rights under the collective bargaining agreement or the individual teacher's contract, and local school board policies, through municipal laws and state laws, up to federal laws (Turpen, 2006). What makes it even more complex is that legal provisions are not universal across the country, with major discrepancies between states, school districts, and even individual schools.

The first set of regulations according to which teachers' rights are regulated is local laws. More specifically, teachers' religion-related conduct may be determined by numerous policies adopted by school boards as well as the teachers' collective bargaining agreement. Even though they represent the lowest level, the local laws may provide more solid protection to teachers as far as their free expression and control over curriculum is concerned than fed- 
eral and state laws (Turpen, 2006). The self-conducted research among American school teachers revealed the existence of substantial differences in school policies between places, which were in the respondents' opinion the result of a difference in the religious makeup of the community. For instance, "In a very strong Christian community, there was no objection to teachers having crosses on their desks, Bible story pictures used in the lesson", said one of the respondents.

Variations occurred even in the same city, sometimes with unexpected results. For instance, a school in Chicago with a predominantly Jewish community, allowed more freedom to talk about religion than a school situated on the west side of Chicago where parents objected to celebrating Christmas, and teachers were instructed not to bring up religion at all due to separation of church and state. The level of diversity of the school community seems to be a decisive factor as well. In a district with diversity of beliefs (Muslim, Jewish, Sikh, Christians), "we have parents waiting for every excuse to sue", reported one of the respondents.

Apart from local laws at a school or district level, another source of laws consists of legislature specific to a particular state as it is at this level that the decisions regarding the funding and directing of education are made. Laws for the state are being enacted by state legislatures, while regulations, policies, and guidelines for education within the particular state are being enacted by state agencies. State-specific laws and constitutions are also applicable by state courts for reaching verdicts in education-related cases (Turpen, 2006). One of the legal documents that decisively determine the range of freedom of religious expression granted to teachers is the Religious Freedom Restoration Act. The significance of the Act will be discussed in the next part of this article addressing the seven key legal concepts.

At a higher, federal level, it is federal statutes, regulations and guidelines, as well as federal courts that decide on the law regarding teachers' religious expression. The federal guidelines addressing the problem of religious expression in public schools were first issued in 1995, and reissued in 1998 and then, without change, in 1999 by the Clinton Administration. The Clinton federal guidelines, delivered to every principal in the country in December of 1999 included a set of guides that incorporated A Teacher's Guide to Religion in the Public Schools. On February 28, 2003 the Bush Administration issued an updated version of the previous federal guidelines, being the version to which the school board in the movie makes references. Even though they are devoid of legal force since the failure to comply with them does not result in administrative disciplinary actions, they provide school administrators with instructions on the correct legal course of action.

Contrary to the opinion of the school board featured in the movie, A Teacher's Guide to Religion in the Public Schools does not outlaw religion-related discussion from a public-school classroom. First of all, it states that teachers may choose to reply to students' questions about their personal religious beliefs "straightforwardly and succinctly in the interest of an open and honest class- 
room environment" (Haynes, 1999a, p. 13). In fact, as stated in a conservative publication Teachers and Religion in Public Schools, "it is best if the teacher is responding to a student's question to him or her about his or her views on a topic" (Turpen, 2006, p. 61) as student-initiated discussion safeguards neutrality of the state; student's speech is attributable to students' only and not to school and as such does not fall under the requirements of the Establishment Clause $^{1}$.

A Teacher's Guide to Religion in the Public Schools outlines the restrictions a teacher should be mindful of when answering students' questions. One of them is the age of the students. Middle and high school students are considered to be capable of telling the difference between a personal view and the official position of the school. Moreover, the response is supposed to be brief and not utilized for advancing the teacher's views neither by proselytizing nor by rewarding or punishing students for agreeing or disagreeing with the teacher's religious views (Haynes, 1999a, p. 13). As clarified in Teachers and Religion in Public Schools, the teacher, for instance, should not make the students feel that their grades or treatment by the teacher might in any way be affected by their approval or disapproval of the teacher's religious convictions (Turpen, 2006).

Beside the criterion of brevity of teacher's comments, the consideration to students' age, and neutrality, a teacher should also ensure that the discussion is relevant to the subject being taught and that students understand that the teacher's comments represent her or his personal viewpoint - not the view of the school district - by making an appropriate disclaimer (Turpen, 2006). The First Amendment guide also instructs teachers to teach "through attribution (e.g., by using such phrases as 'most Buddhists believe ...' or 'according to the Hebrew scriptures ...')" (Haynes, 1999a, p. 10) to avoid injecting their personal religious views. In fact, this is exactly what the protagonist seemed to be doing by making references to the records found in the Gospel of Matthew, as she says, "The writer of the Gospel of Matthew records Jesus as saying", (Cronk, 2016) followed by an immediate reference to Dr. King who was inspired by the Scripture in this respect as well as the role Gandhi played in furnishing the method of a nonviolence approach.

The guides not only permit a teacher's response to students' spontaneous questions, but also claim that in the school curriculum there is a constitutionally permissible place for teaching about religion. For example, making reference to the National Standards for History, published by the National Center for History in the Schools, Haynes (1999a) observes:

The elaborated standards in world history are particularly rich in religious references, examining the basic beliefs and practices of the major religions as well as how these faiths influenced the development of civilization in succes-

1 In a seminal 1990 case, Westside Community Schools v. Merges, the Supreme Court made a clear distinction between school actions representing the state and students' speech as private speech, and therefore protected under the Free Exercise and Free Speech Clauses. Voluntary, student-initiated and student-led religious activities became recognized as incapable of violating the Establishment Clause, and thus permissible on the school grounds. 
sive historical periods. While the U.S. history standards include religion less frequently, many historical developments and contributions that were influenced by religion are nevertheless represented. (p. 9)

Making references to the Bible and particularly to the teaching of Jesus, as the protagonist does in the movie, is recognized as permitted. Another official guide issued by the First Amendment Centre, The Bible and Public Schools, states the following:

Educators widely agree that study about religion, where appropriate, is an important part of a complete education. Part of that study includes learning about the Bible in courses such as literature and history. Knowledge of biblical stories and concepts contributes to our understanding of literature, history, law, art, and contemporary society. (Haynes, 1999b, p. 9)

In a similar vein, the Alliance Defending Freedom (2013) instructs school officials in their guide, Teachers' Religious Expression in Public Schools, that "a public school teacher may objectively teach the Bible and discuss the life of Jesus during history, literature, geography, sociology, or other similar class curriculum" (p. 2). The requirement of objectivity is satisfied when "all facets of a subject, both secular and religious [are presented]" (Alliance Defending Freedom, 2013, p. 1) by the teacher. Drawing parallels of the approach to social justice of two historical figures while discussing the curricular topic appears to fall into this category. In a similar, real-life event, Samuel J. Smith reports a situation when he served as a middle school teacher in inner city Houston public schools. During classes he asked the students to compare the lives of Harriet Tubman to Moses. The author argues that unless a parallel is drawn between Harriet Tubman and Moses, a proper understanding of the role of the latter is impeded. "How could one effectively teach about and explain her nickname of 'Moses' without explaining the parallel of the Hebrew nation leader named Moses?" (Smith, 2007) asks the teacher.

In J. Smith's case, his request met with harsh opposition from the side of students who claimed that it was illegal to teach the Bible. This particular example seems to be just one out of many similar events in public schools. As evidenced by the results of the Bible Literacy Project, despite the provisions included in the guidelines issued by the First Amendment Centre (Haynes, 1999b, p. 9)², a primary reason for the deficiency of biblical knowledge among high school students was found to be the misconception both on the part of teachers and students that mixing Bible and public education is illegal. Some educators expressed their discomfort and fear over the issue of teaching the Bible in school: they did not wish to incur potential problems, or "get in trouble" (Inc., 2005). A number of teachers reported being discouraged by students asking

2 At a secondary level "public schools should include study about religion in some depth [and] such study may include study about the Bible, where appropriate, in history and literature courses as well as in elective courses that deal with the Bible". At an elementary level, in turn, "students are introduced to the basic ideas and practices [in the context of] the study of family, community, various cultures, the nation, and other themes and topics... Stories drawn from various religious faiths may be included among the wide variety of stories read by students... One court has permitted elective Bible courses at the elementary level"(see: Haynes, 1999, p. 9) 
questions about the legality of teaching the Bible in the classroom. "Navigating religious rights of students and teachers can be precarious and even costly if it leads to litigation", concludes Smith (2007). The movie protagonist was liable for her actions, which exemplifies the anxiety religious teachers have to cope with in public schools.

Apart from in-class student-teacher contact time, the sources direct teachers to "refrain from initiating conversations concerning the teacher's religious beliefs while students are required to be on campus", which would include "any time students are required to be on campus as well as the time students immediately arrive for the purposes of attending school for instruction, lunch time, and the time immediately prior to students' departure after the instructional day" (Soronen, 2008, p. 60). The rationale behind this prohibition is based on the mandatory character of school and impressionability of students. In situations when teachers' views are in conflict with those held by students and their families, it may amount to keeping them captive audience and, thus result in violation of students' religious freedom rights (Soronen, 2008).

Turpen (2006) objects to these restrictions claiming that a "Teacher's expression outside of the classroom should not be considered curricular speech and, therefore, should be more protected from restrictions by school administrators" (p. 61). If teachers were deprived of the right to discuss their religious viewpoints on school grounds as inconsistent with the Establishment Clause, they would be deprived of the possibility to respond to students' inquiries during contact time, argues the author. What is more, if other teachers are permitted to discuss their personal views on nonreligious subjects, "[a] teacher should be able to discuss his or her religious viewpoints with students, particularly in response to a student's questions and particularly outside of the classroom during lunch, or before class begins or after class ends" (Turpen, 2006, p. 61).

A Teacher's Guide to Religion in the Public Schools extends this right to discuss religious topics to fellow teachers, when it states that:

If a group of teachers wishes to meet for prayer or scriptural study in the faculty lounge during their free time in the school day, we see no constitutional reason why they may not be permitted to do so as long as the activity is outside the presence of students and does not interfere with their duties or the rights of other teachers (Haynes, 1999a, p. 13)

The regulation runs contrary to the charges brought against Ms. Wesley that she discusses her faith with fellow teachers in the teachers' lounge (Cronk, 2016).

Even though the guidelines have been adopted and disseminated by the Department of Education, following them does not safeguard teachers from being directed to stop discussing religious viewpoints in class discussion if the comments are not allowed by the school district. If teachers are directed by the supervisor not to express their religious viewpoints in the classroom, conservative sources suggest they may attempt to justify their actions. Teachers should clarify the permissibility of the comments and the scope of liberty they 
may exercise due to the fact that not all their personal religious expression is prohibited by the Establishment Clause.

However, as stressed in legal debate, a teacher's right to free speech is being weighed against a school district's interest in avoiding Establishment Clause violation. Working towards this interest, as Stacey (2008) puts it, "[p] ublic school officials have the authority to prevent teachers from giving students and others the impression that the school prefers a particular religion or religion in general" (p. 60). Besides averting the risk of differential treatment, the "[s]chool districts have a constitutional duty to make certain that teachers subsidized with public funds do not inculcate religion", explains the author. Consequently, "[a] teacher may be prohibited from reading his Bible aloud to students and discussing religion during class, in contravention not only of the Constitution, but also of the lesson plans left for him" (Stacey, 2008).

The disciplinary procedure is usually preceded by a warning from supervisors, but, as the storyline of the movie features, and school history confirms, "[w] hile it is unlikely for a teacher to be disciplined [even] without prior warning, it is possible" (Turpen, 2006, p. 57) ${ }^{3}$. In the case of Ms. Wesley, when asked whether her response to a student's question was "in line with district policy, ... [a]s well as in compliance with state and federal guidelines," she acknowledged it was (Cronk, 2016).

\section{LEGAL CONCEPTS DETERMINING THE SCOPE OF TEACHERS' RELIGIOUS EXPRESSION}

Ms. Wesley, who does not recount her statement in front of the school board and refuses to apologize for her actions, faces a lawsuit filed by the students' parents who are supported by the American Civil Liberties Union (ACLU). In real life, if a lawsuit related to a teacher's religious expression is filed at a federal level, it begins in a district court in a given state and can be appealed to the federal court of appeals, whose verdicts are law only in the specific states under that particular court's jurisdiction. If the appeal is rejected, the losing party may appeal the case to the Supreme Court whose decisions are binding at all levels throughout the country. The Court hears only selected cases, and the number of cases that relate to religion, public schools, or freedom of speech ranges from 5 to 6 per year (Turpen, 2006, p. 57). Most probably, the dispute featured in the movie is set in a federal court, and the losing party refuses to make an appeal to a court of a higher instance.

Just as the scope of freedom exercised by teachers is a complex and diverse issue due to the complexity of the legal system, the complexity marks the very process of negotiating the scope of teachers' rights in the courts of law. The

3 The authors give an example of Helland v. South Bend Community School Corp., 93 F.3d 327, 331 (7th Cir. 1996) where school directed a teacher to refrain from expressions of religious viewpoints in the classroom and like settings. They state that " $[\mathrm{t}]$ he existence of a policy likely would be sufficient notice, even if the teacher were not actually aware of the policy". 
reason rests with the complexity and diversity of legal concepts employed in the debate. In other words, whether or not a particular religious expression is permissible for teachers in a school context is determined on the basis of as many as seven key legal concepts. Since the concepts present a different perspective on the issue, it is actually how they are weighed against one another that determines the outcome of the legal process. Variety abounds, as "different courts (and even judges within a particular court) sometimes weigh these factors very differently, causing a considerable difference in the outcomes of cases depending on the court or the judges hearing the case" (Turpen, 2006, p. 13).

Two of the core concepts are provided by the Establishment Clause of the First Amendment to the US Constitution, and additionally by state establishment clauses incorporated in state constitutions. In the movie, the judge presiding over the case against the History teacher initiates the proceedings with a reading of both First Amendment clauses (the Establishment Clause and the Free Exercise Clause) and stressing that they remain in tension (Cronk, 2016). The legislature prohibits school administrators and teachers, as state officials representing the government, from making "law respecting an establishment of religion." The problematic issue is when teachers' actions should be identified as the government's own actions and when they should be identified actions conducted as private individuals who are entitled to advancing, promoting or proclaiming religious ideas and expression.

The plaintiff in the movie production strongly argues for total identification of the defendant's actions with the government actions. He calls for the total separation of the state and church, which is a flagship statement of liberal organizations such as ACLU that he represents. The line of the defense emphasizes Ms. Wesley's actions as a private individual whose right to retain her religious identity should not be denied even if she holds her position as a state official. This standpoint is propagated by conservative organizations, which argue that " $[t]$ here are times when a teacher should not be treated as a government official even though he or she is on school property, but instead should be treated as a private citizen expressing religious viewpoints" (Turpen, 2006, p. 14). The film jury upholds these rights. The courts in real life, however, would rather opt for their denial, as stated in Teachers and Religion in Public Schools, " $[\mathrm{t}]$ he courts have tended to treat a teacher as a government official, subject to Establishment Clause restrictions, rather than a private individual, exercising rights of freedom of speech and religion" (Turpen, 2006, p. 14).

The Free Exercise Clause upholds the speech rights of teachers, as evidenced by Mr. Justice Fortas in the Supreme Court case Tinker v. Des Moines Independent School District (1969): "First Amendment rights, applied in light of the special characteristics of the school environment, are available to teachers and students. It can hardly be argued that either students or teachers shed their constitutional rights to freedom of speech or expression at the schoolhouse gate." Despite these provisions, however, teachers' religious speech might still be impeded as it might not be qualified as a topic "of public concern", and even if recognized as such - and thus eligible to protection - teacher's freedom of 
speech might be outweighed by "the government's interest in the efficiency and harmony of its workplace" (Turpen, 2006, p. 17).

As James C. Carper and Thomas C. Hunt (2009) observe, the Free Exercise of Religion guarantees have been weakened by the fact that "the Supreme Court has narrowed its focus to the principles of neutrality and equality" (p. 207). Religious conduct continues to be protected from discrimination; however, the protection is limited to instances when the government fails to allow the conduct done for religious purposes while it allows the same conduct done for nonreligious reasons (Turpen, 2006, p. 18).

Another concept is based on the Freedom of Speech, which is also one of the freedoms guaranteed by the First Amendment. Since 1983 the freedom of teachers to express themselves religiously in schools, including instructional time with students, has been increasingly restricted by the introduction of the three tiers of government facilities by the Supreme Court. ${ }^{4}$ During school hours a school is generally considered a nonpublic forum, which on the one hand gives school authorities the discretion to impose limitations regarding the type of speakers (which may exclude teachers) or certain topics of speech (which may exclude all non-curricular speech).

What the authorities are not permitted to do, on the other hand, is to discriminate speakers on the basis of their identity as well as on the viewpoint they express. Thus, if nonreligious speakers are allowed and nonreligious views of the topic are presented, schools should allow for the religious speakers and the presentation of topics from a religious perspective. The protection is valid provided that the discussion is identified as an individual's private speech, not government speech which is attributable to the school. Even though schools are typically regarded as nonpublic forum during instructional time, with respect to teachers the courts may determine that the teacher's religious speech at issue cannot be identified as private speech protected by the Freedom of Speech, but entirely as government speech, and is as such subjected to the limitations imposed by the Establishment Clause.

Closely related to the Freedom of Speech is another category, i.e. freedom from viewpoint discrimination. This expression of freedom prohibits the state from imposing censorship on an individual's private speech if the rule of "equal treatment" is applicable, that is when nonreligious speech on the same topic is permitted. Thus, religious speech cannot be singled out neither for advancement nor prohibition, neither for accommodation nor for burdens. Despite the fact that the Supreme Court verdicts in three landmark cases ${ }^{5}$ were

4 The three fora include the traditional public forum, the limited public forum and the nonpublic forum. Schools do not qualify as the first type of forum since they do not provide for an content-unrestricted expression of views by private individuals. Except for the non-instructional time, nor do they qualify as limited public forum, which allows private individuals and groups to have access to their facilities in order to express their religious views freely, without restriction due to the speech content.

5 Lamb's Chapel v. Center Moriches Union Free School District, 508 U.S. 384 (1993), Rosenberger v. University of Virginia, 515 U.S. 819 (1995), Good News Club v. Milford Central School, 533 U.S. 98 (2001). 
favorable for religious expression by students or community groups in educational institutions, they do not guarantee that the protection of religious expression applies to teachers.

In the movie the question of presenting a religious viewpoint when a secular one is presented appears in a number of contexts. First of all, in the classroom, when the nonviolent form of protest is discussed, it is debated in the context of the movement inspired by the teachings of Gandhi and then those of Jesus. Secondly, during the court proceedings, when the full name of the school is debated, Ms. Wesley's attorney points out that it fails to account for the religious inspiration of Dr. Luther King's civil rights movement. And finally, it appears in an informal discussion between Ms. Wesley and her attorney related to discussing religious historical figures and nonreligious ones on an equal basis.

Provided that nonreligious content is presented, all of these instances call for the nondiscriminatory treatment of Christian content. The instances are illustrative of the conservative position, exemplified in the following statement of Turpen (2006):

Some courts have continued to restrict teachers' religious expression, despite a viewpoint discrimination argument, because the judges mistakenly believe the Establishment Clause concerns created by teachers' religious expression justify the school officials' viewpoint discrimination. (p. 16)

The next factor that regulates the scope of teachers' freedom of religious expression is the rights of school administrators to control the curriculum. The courts often weigh a teacher's free speech claims against curricular supervision of school authorities, and increasingly administrators use the latter as justification for curtailing teachers' religious expression. Instrumental for this trend was a court case Hazelwood v. Kuhlmeier (1988), which upheld the school authorities' right to regulate students' religious speech for legitimate pedagogical reasons. The verdict was applied by several courts to teachers' religious expression in the classroom, both in regard to the use of religious materials and the teacher's comments on religious issues, even if both were constitutionally appropriate and permissible. ${ }^{6}$

Finally, teachers' religious expression is influenced by whether or not a given state has passed the aforementioned state Religious Freedom Restoration Act (RFRA). The legislature restored the provision of the RFRA (1993) at a state level that protected the religious exercise of an individual from being burdened by laws that are neutral towards religion. It stated that "governments should not substantially burden religious exercise without compelling

6 The constitutionality of the incorporation of religious content into the curriculum when appropriate and if done in an objective and neutral manner was stated in Religious Liberty, Public Education, and the Future of American Democracy: A Statement of Principles published by The Freedom Forum First Amendment Center at Vanderbilt University in 1995. The booklet was a part of The New Consensus on Teaching about Religion reached by coalition of diverse groups in late 1990s. 
justification" ${ }^{\prime 7}$. What is more, the government was obliged to take the least restrictive means possible to achieve its objective. Unless the government is able to prove to the courts that this high standard had been satisfied, the government policy that limits the constitutional freedom of religion would be declared unconstitutional (Stronks, \& Stronks, 1999, p. 66).

Thus, teachers who enjoy the benefits of a state RFRA may not have their religious conduct restricted unless the government demonstrates that it has a compelling interest (such as public safety, peace and order) in imposing the limitations and the objective of the restrictive policy cannot be achieved by a less restrictive means. The legislature does not provide an absolute safeguard for teachers' religious conduct, since as stated by Turpen (2006), "it is possible [that] the courts might decide that school administrators' rationale for restricting the religious conduct or expression is a compelling one" (p. 18).

\section{THE SOURCE OF DISCREPANCY BETWEEN THE SUPREME COURT PROTECTION AND THE LOWER COURTS DECISIONS}

As evident from the presented outline, the scope of freedom public school teachers may enjoy as they work in their capacity as state employees is heavily regulated by multiple and complex legislation that varies from state to state and even from district to district within an individual state. Additionally, cases related to religion in the public schools are "highly fact-specific" (Turpen, 2006, p. 18) so the constitutionality of a given religious expression may be determined by a difference in one or two facts, even if the facts may appear insignificant.

The most striking divergence, however, seems to be that despite the fact that Supreme Court decisions ${ }^{8}$ seem to ensure equal protection of religious and nonreligious viewpoints, as stated by Turpen (2006), "it is not clear whether lower courts will apply this Supreme Court precedent to protect a teacher's religious expression" (p. 61). In fact, the authors explain, "[i]f the teacher is warned to stop such discussions, the teacher should be aware that many courts will not adequately protect teachers' religious expression" (p. 61).

The sources explain the reasons for this discrepancy between the Supreme Court's line of decisions, which, as it has been previously stated, are binding at all levels throughout the country, and the verdicts reached by lower courts as basing their verdicts of the Supreme Court cases that are not specific to education or to teachers' rights of religious expression. The following three lines of Supreme Court decisions are identified by Turpen (2006, p. 55):

7 The legislation gained a positive response across the nation and as of April 2015 as many as 21 states have adopted their own mini-RFRAs, the most recent being the state of Indiana and Arkansas, which introduced their legislation in 2015. Apart from that, some other states have interpreted their state constitutions so that they are more in line with Sherbert than with Smith, so approximately ten more states "have language in their state constitutions that generally accomplishes the same goal" (see: Walsh, 2015).

8 Lamb's Chapel v. Center Moriches Union Free School District, Rosenberger v. University of Virginia, and Good News Club v. Milford Central School. 
The first line of lower courts' verdicts is based on Hazelwood $v$. Kuhlmeier (1988) which did not refer to either teachers' speech or religious expression, but to freedom of speech on school grounds in general. The Court decided to uphold the power of school officials to control and restrict the freedom of students to publish articles in the student-edited school newspaper. The rationale for the decision was based on the premise that the newspaper was part of a journalism course at the school, and thus part of the curriculum, and as such it can be subjected to regulations by school authorities provided that there is "a legitimate pedagogical reason" (Turpen, 2006, p. 55) for the restriction. The Hazelwood "Pedagogical Concern" test has been interpreted broadly by many lower courts to incorporate teachers' in-class speech, which gave permission to school authorities to censor any expression representing the public school for legitimate pedagogical reasons.

As Matthew Baker (2009) observes, the test has become the leading approach the lower courts adopt to teachers' classroom speech, thus decreasing their chance for succeeding in lawsuits filed on the grounds of First Amendment rights violation (p. 723). Some commentators, as the author suggests, argue that equaling the censorship of students' speech with a teacher's expression not only diminishes the position of teachers as those who define "legitimate pedagogical concerns" but also - given the fact that teacher in-class speech is for the most part curricular - it further deprives teacher-student speech of First Amendment protection, limiting it to 'random comments' in the classroom (Baker, 2009, p. 724).

The second line of Supreme Court decisions, again not involving teacher speech, but being utilized to restrict teacher speech, resulted in the approach that when an individual's speech is recognized as the government's own speech, the government may restrict it without having to justify its actions.

Finally, the third line of verdicts reached in lower courts based on the Supreme Courts' decisions is related to teachers' constitutional rights as public employees. The courts decided to use the so called "Pickering test" (Pickering $v$. $B d$. of Educ., 1968) to in-class teacher speech as they determined that a teacher's primary relation to school is that of employer-employee due to the fact that 'teacher's speech' is what they are paid to do by the state. This two-step test first analyses teacher's speech to determine whether or not it involves a matter of public concern, as the protection of the First Amendment extends only to content that does. Secondly, the court must decide if the government's interest in sustaining the workplace efficiency and orderly functioning outweighs the teacher's interest in expression. The test protects the teacher's right to speak on matters of public concern even in his or her capacity as a state employee, which is the essence of what teachers do with students. However, as Emily White Kirsch (2010) argues, "the Pickering test fails to account for the unique environment of public school teachers [as it offers the right] to speak outside of the curriculum, which is non-existent for some teachers, such as math teachers, while other teachers, such as social studies or literature teachers, regularly touch on matters of public concern" (p. 205). 
While the Pickering test appears to offer some limited protection to teachers' in-class speech, the Rust test based on the Court's decision in Rust v. Sullivan (1991), stresses the issue of teachers as state officials even further. Under this test the government should retain full control over teacher in-class instruction. When a teacher speaks it is in fact "the state and local governments, through their curriculums, [that] are conveying a particular message [through the subjects and viewpoints, and they] should be able to ensure that their message is not distorted" (Kirsch, 2010, p. 201). Since it is the government that speaks by means of the teacher, it is the government that exercises editorial control over the range of viewpoints (ideas, issues, values, and subjects) it would allow to be taught as well as it is the government that bears the ultimate responsibility for what message is being conveyed in the classroom. In sum, as Kirsch (2010) argues, when in class, "teachers should have no First Amendment right to speak outside of the prescribed curriculum" (p. 201) and are allowed to express their views only outside the classroom.

\section{CONCLUSION}

Considering the decisions of the lower courts and their tendency to curtail teachers' religious expression as non-curricular and so running afoul of the provisions of the Establishment Clause, it seems well-substantiated to state that the authors of the movie script "God's Not Dead 2" did not go too far staging a court trial of their protagonist as consequence of her replying to a student's innocent question. It is indeed symptomatic of real-life scenarios religious teachers face in American schools. Even if not every single teacher may face a trial, it definitely has an impact on the atmosphere in the classroom, as one of the interviewed teachers claims that "[w]e are being restricted in what we can do at school. There is high level of stress in the classroom. If it you talk about something that is controversial, you are done."If this is the case, it creates several types of risk. Firstly, the risk of placing educating the youth on the rights of citizens in jeopardy, as Justice Jackson stated in West Virginia State Board of Education v. Barnette (1943), "educating the young for citizenship is reason for scrupulous protection of Constitutional freedoms of the individual, if we are not to strangle the free mind at its source and teach youth to discount important principles of our government as mere platitudes."

Secondly, the acceleration of the already existing trend to resort to homeschooling for religious reasons, as one of the respondents reported, "Some of the Christian schools are growing and [so are] Catholic schools. Some tripled in size." The situation definitely calls for the revision of teacher training programs to instruct school officials on their rights of religious expression and the boundaries they may operate within, so that the following statement of an interviewed teacher will become a thing of the past, "[h]ow to cope with religious issues is not taught during teacher training apart from the fact they tell us to keep it to yourself." 


\section{REFERENCES}

1. Baker, M. (2009). A Teacher's Right to Remain Silent: Reasonable Accommodation of Negative Speech Rights in the Classroom. Brigham Young University Law Review, 705(3), 705-740.

2. Bible Literacy Project, Inc. (2005). Bible Literacy Report: What do American teens need to know and what do they know. Front Royal, VA. Retrieved from http://www.bibleliteracyproject.org/ Secure/Documents/BibleLiteracyReport2005.pdf

3. Center for Law and Religious Freedom, Christian Legal Society, \& Christian Educators Association International. (2006). Teachers and Religion in Public Schools. (F. Turpen, Ed.) (Vol. 4). Pasadena, California: Christian Educators Association International "Light in Learning Press." Retrieved from http://www.clsnet.org/ document.doc?id=130

4. Cronk, H. (Producer), \& Hatcher-Travis E. et. al. (Director). (2016). God's not dead 2. [Motion picture]. United States: Pure Flix.

5. Religious Liberty, Public Education, and the Future of American Democracy: A Statement of Principles. (1995). Nashville, TN: The Freedom Forum First Amendment Center at Vanderbilt University. Retrieved from http:/ / files.eric.ed.gov/fulltext/ED387420.pdf

6. Smith, S. J. (2007). Navigating Religious Rights of Teachers and Students: Establishment, Accommodation, Neutrality, or Hostility? Presented at the NCPEA Conference, Chicago. Retrieved from http://digitalcommons.liberty.edu/context/educ_fac_pubs/article/1047/type/native/ viewcontent

7. Stacey, V. R. (2008). Accommodation of School Employee Religious Expression and Practices. In L. Soronen (Ed.), Religion and Public Schools: Striking a Constitutional Balance (3rd ed., p. 55). Austin, Texas: NSBA Council of School Attorneys. Retrieved from https://www. google.pl $/$ url? $\mathrm{sa}=\mathrm{t} \& \mathrm{rct}=\mathrm{j} \& \mathrm{q}=\& \mathrm{esrc}=\mathrm{s} \&$ source $=$ web\&cd $=5 \& \mathrm{cad}=\mathrm{rja} \& u a c t=8 \& v e d=0 \mathrm{ahUK}$ Ewi7v7HH9KzYAhVPDOwKHYxPACEQFghNMAQ\&url=https\%3A\%2F\%2Fsecure.nsba. org\%2Fstorefront\%2Fdetail.aspx\%3Fid\%3D1208\&usg=AOvVaw1a8Fk4VfHtFzWcfSzkV0ol

8. Stronks, J. K. (1999). Christian teachers in public schools : a guide for teachers, administrators, and parents. Grand Rapids, Mich.: Baker Books.

9. Walsh, M. (2015). Religious-Freedom Laws Add to Schools' Complex Duties. Education Week. Retrieved from http://www.edweek.org/ew/articles/2015/04/10/religious-freedomlaws-add-to-schools-complex-duties.html

10. White Kirsch, E. (2010). First Amendment Protection of Teachers' Instructional Speech: Extending Rust v. Sullivan to Ensure That Teachers Do Not Distort the Government Message. Cleveland State Law Review, 58, 185-216. 